\title{
The Development Digital Book Media with Learning Model Contextual Teaching And Learning to Improve Student Mathematical Economic Problem Solving Skills
}

\author{
Achmad Buchori $^{1 *}$, Agnita Siska Pramasdyahsari², Siti Kholifah ${ }^{3}$ \\ 1,2 PGRI University of Semarang. Jl. Sidodadi Timur Nomor 24-Dr. Cipto Semarang, Indonesia \\ ${ }^{3}$ STEKOM University of Semarang. Jl. Majapahit 605 Semarang, Indonesia \\ Corresponding author. Email: achmadbuchori@upgris.ac.id
}

\begin{abstract}
This study aims to determine the development process, practicality, validity level, and media effectiveness digital book with CTL (learning model Contextual Teaching and Learning) to improve students' mathematical economic problem skills. The research method used is $\mathrm{R} \& \mathrm{D}$ research using the ADDIE development model (Analysis, Design, Development, Implementation, Evaluation). Research Subjects are seventh grade students of SMP Negeri 4 Semarang in 2019/2020 academic year. By choosing two classes namely class VII E as experimental class and VII G as a control class Before being tested in teaching materials validation tests were conducted by media experts, material experts and media design experts. Results of media, material, design expert validation. media, student responses and teacher responses have good criteria, namely for media experts, $93.33 \%$ were obtained, instructional media design experts $80.88 \%$, material experts obtained $87.3 \%$, the media was feasible to use, and teacher responses $87.5 \%$, and student responses $87.05 \%$.The media is practical to use. From the calculation of the N-Gain Test for the experimental and control classes have NGain the average score is the difference is 0.419 and 0.132 .
\end{abstract}

Keywords: Development, digital book Media, CTL Learning Model Mathematical economic, Problem Solving

\section{INTRODUCTION}

Education is an important effort that must be carried out by families, communities, and the government through teaching activities, guidance, or exercises that take place at school or outside school that can help students become creative and independent individuals. Education is a character forming an individual in facing life's challenges. The Law of the Republic of Indonesia Number 20 of 2003 Chapter II Article 3 concerning National Education System states that National Education functions to develop capabilities and form dignified national character and civilization in order to digest the life of the nation, aiming at developing potential students to become human believers and fear God the Supreme, noble, healthy, knowledgeable, capable, creative, independent, and a democratic and responsible citizen [1]. Specific problem solving strategies recommended in the School Mathematics Principles and Standards of the Mathematics National Council of Mathematics include using diagrams, looking for patterns, trying values or special cases, and requiring instructional attention. NCTM also suggests that teachers give students the opportunity to apply strategy problem solving in all areas of mathematical content [2].

In mathematics learning, teachers play a very important role in determining the success of student learning in mathematics. Of course the teacher is required to be able to determine the learning model that can improve the success of these students. In implementing a fun learning process. Mathematics is a very important field of study in the education system because mathematics is a science that underlies the development 
of science and technology, has an important role in various disciplines and can develop students' ability to think and be logical, critical, careful and responsible. Therefore mathematics is taught at every level of education, from basic education to higher education [3].

Learning mathematics that is fun at school will be able to evoke a sense of excitement which is the main capital in creating students' understanding of the material being studied. A teacher with his professional abilities must be able to create a learning atmosphere that gives rise to interest in learning and attraction to the material being taught. One of the efforts that can be done by the teacher is the skill in determining the learning model that is suitable with the learning objectives, the condition of the students and the conditions of the learning place.

Based on preliminary observations conducted at Junior High School 4 Semarang. In the learning process students look less interested, less enthusiastic, and less enthusiastic in learning. Most students only listen to textbooks and teachers and how to teach they still use the lecture method. Because the method, causes learning to be less effective, uninteresting, and slow to understand, it has an impact on students' mathematical problem solving abilities. In addition, the attention of students in mathematics tends to be passive, less courageous to ask questions and submit answers, oriented to one correct answer, and class activities that are often done are simply recording or copying. Learning activities like this do not develop students' abilities in problem solving, reasoning, and mathematical communication. Teachers also rarely use power point media in learning activities, because the teacher is quite old and does not understand the growing learning media.

Judging from the average test scores of students in Social Arithmetic material in the 2020/2021 school year with conventional learning it was considered to be less than optimal because most student repetition values had not yet reached Minimal completeness criteria. So that it can be concluded that most students still feel difficulties in the material of Social Arithmetic with conventional learning. So that we need a learning media that can be used by teachers in explaining material or in solving math problems and can be used by students to play interesting and fun games and can provide a concrete picture so that students can improve students' mathematical problem solving abilities.

As a result, students' cognitive abilities are very weak because the usual learning activities only encourage students to think at a low level. So that student achievement is still under the Minimal completeness criteria. Due to the low mastery of mathematical material shows that there is a problem that needs to be solved immediately. This is done so that students can more easily understand and understand the concepts of mathematics, so that they can improve. Interviews were also conducted with several students about what problems were received during mathematics learning. The average student says that there is material that is difficult to understand and the learning media is less attractive. The average student cannot solve the problem well, students have difficulty understanding the problem that is not able to make a settlement plan, unable to make a mathematical model and not re-checking the answers that have been completed. Most of these students tend to avoid problems that require good problem solving skills, students only like routine and procedural questions.

From the problem above shows that the teacher must be able to keep up with existing technological developments. In the learning process the teacher is required to create a learning media that can attract students' attention and the material is easily understood by students. Learning media can be used as an alternative source of learning by teachers if in reality the provision of direct learning experiences is difficult to do. Many experts have examined the role of media in the learning process [1]

Learning media includes tools that are physically used to convey the contents of the material [4]. Besides that it appears that learning media is a tool used as an intermediary in the learning process. Effective learning media are not determined by the cost or use or use of the media, but depend on the compatibility between the characteristics of the media and the material delivered, and according to the stage of development of the child, including comics. Comics as part of print media, can be developed as an alternative learning media.

Learning media packaged in comic form can be used as a variation of learning media. This comic media has the potential to be preferred by students, because the pictures in the comic can turn on the written text accompanying it. With images, lengthy and complicated explanations of the text or topics of learning that are read can be more easily understood and remembered by students. Even students can understand and imagine first what actually is the core of the topic of the lesson that he reads through the existing images [1]. Learning media have been classified according to their attributes which include printed \& non-printed material, projection \& non-projection material, real objects, 2D 3D objects, audio \& video. Effective use of media in the classes of depends on creativity and innovation, ways of delivery and learning planning strategies. The choice of media and learning activities is based on the principles of the learning design model. Thus, although learning media helps to foster students' understanding of content, it may not work effectively if the teacher treats the media as a separate entity from the teaching and learning process [5].

Given that comics and digital media currently tend to be favored by teenagers, then it is considered that Digital Book will be effective if it is used in the delivery of learning material in class. Making learning media Digital 
Book can produce learning multimedia that is innovative, interactive, effective and interesting so that the multimedia can be responded to by students in the school, as well as helping students focus attention on learning [4]. One of them is by using digital comics that can be accessed through the internet which is better known as digital book This media has various advantages including, not weathered, easily distributed and interactive. These advantages are quite interesting if Digital Book can be developed in the world of education and become one of the breakthroughs in the selection of learning media in schools [6]. Learning material can be used as an interactive experience to teach others, such as children or students, and can be used to improve reading skills and reading comprehension. Customized content for teaching purposes can be generated quickly in paper or electronic format, and scanned / processed in real-time or almost real-time to produce electronic audio and video output. In addition, Digital Book metadata can be created by one device and stored in a file that will be rendered by another device (without OCR processing or indexing) [7].

Based on factors that are thought to be a problem with learning achievement in Mathematics, researchers will apply the learning model Contextual Teaching and Learning (CTL) as one of the learning strategies that can help improve students' abilities in solving mathematical problems. In addition CTL or problem based learning is a learning approach that uses real world problems as a context for students to learn about critical thinking and mathematical problem solving skills, and to acquire essential knowledge and concepts from subject matter [8] CTL is a process that is built on the recognition that some students learn more effectively when they are taught in a real-world context, rather than abstractly [9].

CTL learning models become more interesting because they have to do with life and real things so students be enthusiastic and motivated in teaching and learning activities. The CTL model is based on a constructivism approach that is thought to improve students' mathematical understanding and disposition. In its implementation, the CTL model can be assisted by the presence of appropriate media so that learning can be more interesting. The CTL model associates subject matter with the daily lives of students, so media is needed that is able to present real life in learning, one of which is mathematical comics. The right media and in accordance with the learning objectives will be able to improve the learning experience so that students can enhance learning outcomes CTL characteristics, as opposed to traditional academic models: Focus on concrete skills and knowledge needed in work and life [9].

The existence of mathematical comics is expected to provide more interesting learning for students [10]. With the existence of mathematical comics as a medium it is hoped that it can improve students' mathematical understanding and disposition. Mathematical comics in this study contain stories in everyday life that indirectly present mathematical problems [11]. Comics have great potential as learning media. The combination of images and text can enhance students' understanding of the concepts learned. Through teacher guidance, comics can function as a bridge to foster interest in reading according to the level of thinking of students, which ultimately can also increase students' motivation and mathematics learning achievements [12].

The use of Digital Book in learning allows teaching materials to be given using online media on the internet, the internet, or computers. Digital Book in the form of softcopy, allows reading comics on computers and other electronic media, such as mobile phones and even android [14]. The use of Digital Book as a medium of mathematics learning can trigger the desire and interest of students in learning mathematics. In addition, the use of this media will foster student learning independence, because this media is designed so that it is very interesting to read. Thus students will be more interested in reading and studying it themselves [14]. Acording to Bahri and Nasution [15] the average student cannot solve the problem well, students have difficulty understanding the problem which, unable to make a settlement plan, is unable to make a mathematical model and does not check the answers that have been resolved. Most of these students tend to avoid problems that require good problem solving skills, students only like routine and procedural questions

\section{METHOD}

The method used in this study is a research and development (Research and Development / R \& D). Research and development methods are research methods used to research so as to produce new products, and then test the effectiveness of these products [16]. The developed in this study is learning media Digital Book with CTL models on Social Arithmetic material using the ADDIE model. This model consists of five main phases namely Analysis, Design, Development, Implementation, Evaluation [17].

The five phases or stages in the ADDIE model need to be done systemically and systematically. The design model of the ADDIE learning system with its components can be illustrated in the following figure.

Location of this study was conducted in Junior High School 4 Semarang. The time of the study was carried out on May 4 to May 18 2020. The population used in the study was Grade VII students of Junior High School in 2020/2021. The sample in the study was class VII G students as the control class, VII E as the experimental class. Before testing the product, researchers first conducted a test of the question instrument. Test 
instruments were carried out in class VIII A with a total of 32 children as trial samples. The research instrument in this study was a description of 15 test questions with an 80 minute time allocation. The instrument trial analysis was conducted to determine the validity of the items, reliability of the questions, the level of difficulty and the differentiation of the questions. In addition, using questionnaires given to material experts, media experts and instructional media design experts as Digital Book media validation with CTL learning models. While the student response questionnaire and teacher response to the media to find out the practicality of Digital Book media with the CTL model.

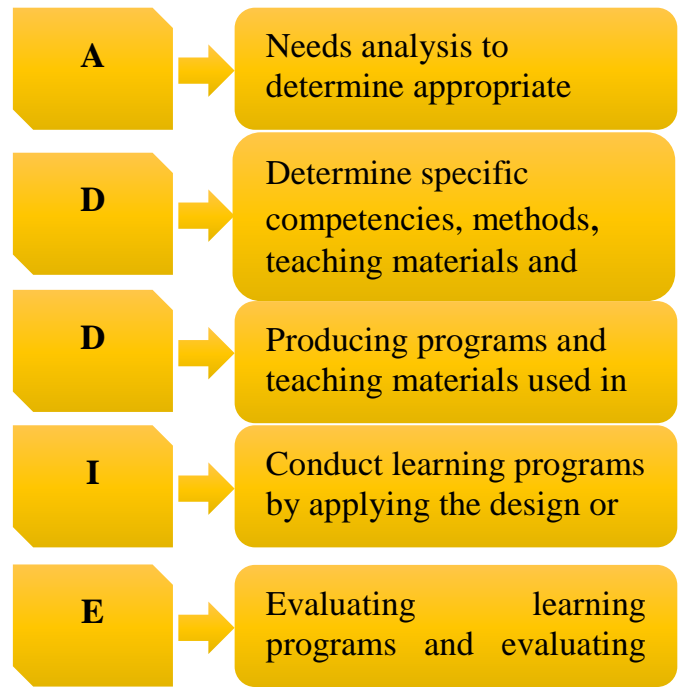

Figure 2.1. ADDIE Component Chart

The analysis carried out consisted of two stages, namely the initial and final analysis. The initial analysis used the pretest value, aiming to determine the initial state of the sample class. Analysis of the initial data using the normality test, homogeneity test,. The normality test was calculated using the Lilliefors test and the homogeneity test was calculated using the Bartlett test. The final data is in the form of posttest value data Social Arithmetic material, which is then analyzed using the normality test, homogeneity test, right-hand t-test and NGain test. To find out the effectiveness of learning is shown by the average mathematics learning outcomes between the two experimental group groups and the Control class.

\section{RESULTS AND DISCUSSION}

In the step Analysis (analysis) consists of two stages, namely performance analysis and needs analysis. Needs analysis is done by observation to collect data about the needs of students. The results of observations of the needs of students of teaching materials and include: (1) Learning resources used for Mathematics subjects are only guided by the worksheet given by the school, the worksheet provided by mathematics subject teachers and printed books. There are no learning innovations using certain media and there are no learning media that can be used by students that are interesting and fun and can provide a concrete picture, (2) Students need teaching media that are able to help in the learning process so that students can improve their ability to solve mathematical problem solving mathematics learning material. Based on the results of these observations, researchers develop learning media by applying interesting learning models that can improve students' mathematical problem solving abilities. The second is Performance Analysis, the results of observations and interviews are used for the performance analysis stage, which is to determine the learning media learning model material and applications that are used to create media. From the results of interviews where the teacher only uses worksheet and conventional learning in learning, the researcher will develop learning media in the form of Digital Book media with CTL learning models of class VII Social Arithmetic material. From the two analyzes, the researcher intends to conduct research on the development of Digital Book media with the CTL learning model to improve students' mathematical problem solving abilities. Like research conducted by Setiawati [11] Students who have a low interest in reading and learning can be improved by using Digital Book media that displays concepts or material through certain storylines and images that are more attractive to students.

In the step Design stage, researchers design teaching materials based on data obtained through the analysis phase. The researcher designed the lesson plan in accordance with the standards of competence and basic competencies through the learning syllabus. Then design learning media in accordance with the lesson plan made on social arithmetic material with the CTL learning model. Learning media begins with giving problems in daily life through questions in the form of stimulus, so that students are more active in the process of learning and learning more meaningfully with CTL. Then there are examples of questions and practice questions. This media designs as attractive as possible, from this stage of planning to produce the initial product. The researcher designed the Digital Book design using a combination of several applications, including: Toondoo, Paint, and Flip Book Maker. From designing using the Toondo application then the downloaded design is in the form of a jpg file after which it is cut to tidy up the frame after converting it into the Flip Book Maker program so that it is arranged in a series of Digital Book containing illustrated stories that certainly contain Social Arithmetic material. In addition, the packaging of material is also made to be easily understood and examples of application to daily life. This is reinforced in the study from Bamrara [18] that teachers believe that the use of systematic design procedures can make education more useful, wellorganized, and can be applied than a less appropriate approach in education planning. 
In the third stage of development (development), at this stage before the toondoo comic learning media was tested in research, it was first validated by the validation of media experts and learning material experts to find out whether toondoo comics were suitable for use or not. The researcher requested his willingness to, media expert validation, material expert validation, validation of instructional media design experts from the University of PGRI Semarang lecturer and teacher at Junior High School 4 Semarang.

Based on media expert validation, this is done to determine the extent to which the product is developed. In this validation stage, values obtained from several aspects, including General Aspects, Aspects of Learning Presentation, Aspects of Language Feasibility, Aspects of Feasibility Integrity with overall percentages obtained $93.33 \%$ which includes very good criteria because it is in the range of $76 \%-100 \%$.

Table 3. 1 Results of Validation Evaluation by Media Experts

\begin{tabular}{|c|c|c|c|}
\hline No & Aspects & $\begin{array}{c}\text { Scores } \\
\text { Expected }\end{array}$ & Feasibility \\
\hline 1 & $\begin{array}{c}\text { Aspects } \\
\text { General }\end{array}$ & $\mathbf{6 9}$ & $\mathbf{9 3 . 3 3 \%}$ \\
\hline 2 & $\begin{array}{c}\text { Aspects of } \\
\text { Learning } \\
\text { Presentation }\end{array}$ & $\mathbf{7 2}$ & $\mathbf{9 3 . 0 6 \%}$ \\
\hline 3 & $\begin{array}{c}\text { Aspects of } \\
\text { Feasibility } \\
\text { Language }\end{array}$ & $\mathbf{3 6}$ & $\mathbf{8 8 . 8 9 \%}$ \\
\hline 4 & $\begin{array}{c}\text { Aspects of } \\
\text { Feasibility } \\
\text { Integrity }\end{array}$ & $\mathbf{7 2}$ & $\mathbf{9 6} \%$ \\
\hline \multicolumn{2}{|c|}{ Total Score } & $\mathbf{2 4 0}$ & $\mathbf{3 7 1 . 1 1 \%}$ \\
\hline \multicolumn{2}{|c|}{ Percentage } & $\mathbf{9 3 . 3 3 \%}$ \\
\hline
\end{tabular}

So that Digital Book media with CTL learning models to improve Mathematical problem solving abilities of students, suitable for use in learning after making revisions in accordance with comments and suggestions from the validator. Following are the suggestions and comments of 3 media validator experts; (1) It is good to need a little improvement. (2) Digital Book is interesting and easy to use, creative products. (3) Digital Book media in the teaching and learning process can create student interest and increase interest in learning. More interesting if there are sound effects.

While the expert validation of this material is done to find out, whether the material presented is appropriate. In this validation stage, values obtained consisting of several aspects including concept aspects, content feasibility aspects, presentation aspects, competency aspects, inquiry approach aspects with overall percentages obtained $80.88 \%$ which are very good criteria because they are in the range of $76 \%-100 \%$.

Table 3. 2 Results of Validation Evaluation by Media Experts

\begin{tabular}{|c|c|c|c|}
\hline No & Aspects & $\begin{array}{c}\text { Scores } \\
\text { Expected }\end{array}$ & Feasibility \\
\hline 1 & Material & $\mathbf{9 6}$ & $\mathbf{8 6 . 4 6 \%}$ \\
\hline 2 & $\begin{array}{c}\text { Use of } \\
\text { words and } \\
\text { languages }\end{array}$ & $\mathbf{4 8}$ & $\mathbf{7 5 \%}$ \\
\hline 3 & $\begin{array}{c}\text { Presentation } \\
\text { Precticality } \\
\text { and } \\
\text { Flexibility }\end{array}$ & $\mathbf{2 4}$ & $\mathbf{7 5 \%}$ \\
\hline \multicolumn{2}{|c|}{ Total Score } & $\mathbf{2 0 4}$ & $\mathbf{3 1 5 . 6 3 \%}$ \\
\hline \multicolumn{3}{|c|}{ Percentage } & $\mathbf{8 0 . 8 8 \%}$ \\
\hline
\end{tabular}

So that Digital book media with CTL learning model to improve students' mathematical problem-solving abilities is appropriate to use in learning after making revisions in accordance with comments and suggestions from the validator. The following are suggestions and comments from 3 material validator experts; (1) material presented in virtual / image. The text is unclear. (2) Digital Book is pretty good, there are only a few typos, please correct it. (3) in making Digital Book use standard Indonesian. Make pictures that match Indonesian characters, avoid irreverent images, adjust Digital Book images according to the material being taught.

Furthermore, the validation of instructional media design experts was carried out to find out whether the design of the learning media presented was appropriate. In this validation stage, the values consist of several aspects, among others Aspects General, Aspects of Accuracy in Drawing Arrangement, Aspects of Drawing Drawings, Aspects of Simplicity of Learning Media, Integration of Visual Aspects, Clarity Aspects of Flow of Stories with $87.3 \%$ which are very good criteria because in the range of $76 \%-100 \%$.

So that Digital book media with CTL learning model to improve the students' mathematical problem solving abilities, worthy of use in learning after making revisions in accordance with comments and suggestions from the validator. Following are the suggestions and comments of 3 learning media design validator experts; (1) Use 
unambiguous language, which aspect of Digital Book design facilitates the CTL model. Note the broken text. Position in Zoom in or Zoom out. (2) It is good. (3) Using Digital Book can be used on certain subject matter. Make clear font sizes and languages that are understood by students.

The next stage is the implementation, at this stage of the experiment the researchers conducted a small group trial and limited trials. Trial of small that serves to determine the readability of Digital Book media before being tested to a limited group. In a small group trial an observation was made of Digital book media by students by filling out a questionnaire to determine the readability of the Digital book media.

From the calculation of the teacher's response is done to find out the teacher's response to the product based on aspects such as general with a percentage as a whole obtained $87.5 \%$ which includes the criteria Very good because it is in the range $76 \%-100 \%$. From the results of the teacher's response that Digital book media with the CTL learning model to improve students' mathematical problem solving skills, it is feasible to use. From the calculation of student responses is done to find out the response of students to products based on aspects including general aspects with a percentage as a whole obtained $86.76 \%$ which includes very good criteria because it is in the range of $76 \%-100 \%$. From the results of student responses that Digital book media with the CTL learning model to improve students' mathematical problem solving skills, it is feasible to use. As well as research conducted by Prasetyowati [19] from the questionnaire results of the students showed that the largest percentage of students' responses to the teaching component was happy and new. Positive response is also given by the teacher on learning devices. The teacher states that the equipment made is good and can assist in the implementation of learning, especially in terms of material construction.

After the Digital book media that had been validated and revised, it taught the experimental class students. After that, implementing the learning program by applying the design that has been made is learning with the development of Digital book media with the CTL learning model to improve students' mathematical problem solving abilities. The following are the results of product testing:

Analysis of the test questions before the questions are given to the experimental class and control class, first the questions are tested on the trial class namely class VIII A to determine the validity, reliability, differentiation and level of difficulty of the test questions. The trial class is a class that has received Social Arithmetic material. Based on the results of the analysis of the test questions obtained valid questions as many as 12 of the 15 description questions. Through calculation of problem reliability, the results show that the test questions are reliable with high classification. Each item has a different level of difficulty, from 15 questions there are 1 difficult question, and 14 moderate questions. Furthermore, the differentiating power from 15 questions is 3 questions categorized poorly, 11 questions with good categories, and 3 questions with very good categories. Overall, from the results of the analysis, from the 15 instrument questions tested, 12 questions were found worthy to be tested.

Here students are required to be active in learning by using Digital Book learning media. Based on the research conducted by Anggraeni [20] shows that the development of e-learning devices using macromedia flash based on CTL is declared valid, feasible and effective for the learning process. Learning media to improve learning outcomes in the realm of knowledge. Learning mathematics with Digital Book media with the CTL learning model is more active in developing linkages with everyday life.

Before the researcher tested the product in the experimental class, the researcher conducted an initial analysis of the pretest values for the experimental class (VII E) and control class (VII G) which included normality and homogeneity. Based on data analysis, the normality of the sample uses the liliefors test with a significant level of 0.05 . In the experimental class $\mathrm{L}_{0}=$ 0.159 and $\mathrm{L}_{\text {table }}=0.167$, because $\mathrm{L}_{0}<\mathrm{L}_{\text {table }}$ then $\mathrm{H}_{0}$ is accepted. While the control class obtained $\mathrm{L}_{0}=0.1610$ and $\mathrm{L}_{\text {table }}=0.1641$. Because $\mathrm{L}_{0}<\mathrm{L}_{\text {table }}$ table then $\mathrm{H}_{0}$ is accepted. So it can be concluded that the two classes come from populations that are normally distributed. As well as research conducted by (Agustina, 2015), namely from the calculation of the experimental class using a Cabri 3D math module with PBL approach obtained $0.0683<0.1569$ then $\mathrm{H} 0$ is accepted, while the control class $0.0754<0.1437$ then then $\mathrm{H} 0$ is accepted. So it was concluded that the two samples came from populations that were normally distributed. Furthermore, after the two populations were proven from populations that were normally distributed, then a homogeneity test was carried out on the two samples. The Homogeneity Test aims to determine whether the two variances of the two groups are the same or not. To calculate homogeneity, the Bartlet test is used. From the bartlett test obtained $\chi_{\text {count }}^{2}=0.286$ for a significant level $\alpha=5 \%$, $\mathrm{dk}=(2-1)=1$ obtained $\chi^{2}$ table $=3.841$. Thus the price $\chi^{2}<\chi$

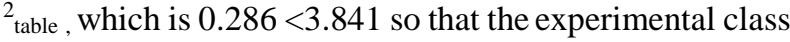
and the control class have the same or variance homogeneous.

The last stage is Evaluation (evaluation). At this stage an evaluation of the impact of Digital book media development was carried out to improve students' mathematical problem solving abilities. Evaluation is done by working on posttest questions given in the experimental class and the control class. Before the posttest questions are given to the experimental and 
control classes, the questions are first tested into the test class to test the validity, reliability, level of difficulty, and distinguishing power. Then after the question is tested only 12 selected questions meet the indicators of mathematical problem solving abilities.

Next, the researcher conducted the final analysis with a liliefors test to determine the normality of the data from the control class (VII G) and the experimental class (VII E). Based on data analysis, the normality of the sample uses the lilifors test with a significant level of 0.05 . In the experimental class $\mathrm{L}_{0}=0.149$ and $\mathrm{L}_{\text {table }}=0.167$, because $\mathrm{L}_{0}<\mathrm{L}_{\text {table }}$ then $\mathrm{H}_{0}$ is accepted. While the control class obtained $\mathrm{L}_{0}=\mathrm{L}_{0}=0.1504$ and $\mathrm{L}_{\text {table }}=0.1641$. Because $\mathrm{L}_{0}$ $<\mathrm{L}_{\text {table }}$ table then $\mathrm{H}_{0}$ is accepted. So it can be concluded that the two classes come from populations that are normally distributed.

After the two samples come from the normal distribution, then the two data are tested by testing the variance homogeneity. The Homogeneity Test aims to determine whether the two variances of the two groups are the same or not. To calculate homogeneity, the Barltlett test is used. From the bartlett test obtained $\chi^{2}$ count $=0.279$ for a significant level $\alpha=5 \%, \mathrm{dk}=(2-1)=1$ obtained $\chi^{2}$ table $=3.841$. Thus the price of $\chi^{2}$ count $<\chi^{2}$ table , which is $0.279<3.841$ so that the experimental class and control class have the same or variance homogeneous.

To find out whether there is a difference between the experimental class using learning media, Digital Book media and the CTL learning model and the control class. The test used is a one-party test (right party). From the analysis obtained $\bar{X}_{1}=86,929$ and $\bar{X}_{2}=77,276, \mathrm{n}_{1}=28$ $\mathrm{n}_{2}=29$ and $\mathrm{Sp}=5,761, \mathrm{t}_{\text {calculated }}=6.324$. With $\mathrm{dk}=55$ and $\alpha=5 \%$, so that it is obtained $\mathrm{t}(0.05 ; 55)=2,004$ where $\mathrm{DK}=\{\mathrm{t} \mid \mathrm{t}>2,004\}$ and $\mathrm{t}=6,324 \in \mathrm{DK}$ then $\mathrm{H}_{0}$ is rejected. So that it can be concluded that the average student learning outcomes of the experimental class after being treated with learning media namely Digital Book media with CTL learning model on Social Arithmetic material class VII $\mathrm{E}$ is better than learning outcomes that use conventional learning on Social Arithmetic class VII G. As with the research conducted by (Buchori, 2015) the effective criteria of the product shown from the learning achievement of the experimental class are better than the control class. analysis using t-test obtained $t_{\text {count }}>t_{\text {table }}$ that is 5.98> 1.71, then Ho is rejected means learning using mobile media learning with realistic mathematical approaches is better than conventional learning.

This shows that the use of Digital Book with the CTL learning model is better than conventional learning. The average value produced by the experimental class is better than the control class, it is caused when the teaching and learning process occurs, the experimental class students are more enthusiastic in participating in learning. From the description above it can be concluded that the learning outcomes of the experimental class using Digital Book media with the CTL learning model are better than the learning outcomes of the control class students who get conventional learning. So that learning using Digital Book media with CTL learning models is more effective than conventional learning.

Based on the N-Gain Test for five categories, in the category of decreasing, low, moderate, fixed, high both experimental and control classes had different NGain scores of 0.419 and 0.132 . This shows the difference between the pretest and posttest scores. In the experimental class the initial pretest had an average score of 77,429 and posttest 86,929 . While the control class at pretest had an average score of 73,966 and post-test 77,276. This shows, that the increase in mathematical problem solving ability of the experimental class is better than the control class. Judging from the aspects of mathematical problem solving abilities between the experimental class and the control class are also the same. That the experimental class is higher than the control class. As well as research conducted by (N. T. Sari \& Ikhsan, 2014) Data analysis was carried out quantitatively performed on normalized gain averages between the two groups of samples using the t-test and $\mathrm{P}$ learning mathematics with a contextual approach was significantly better in improving comprehension and solving skills. students' mathematical problems compared to conventional learning

\section{AUTHORS’ CONTRIBUTIONS}

This research was made by three author, first author make final paper, second author collecting data and third author analysis data

\section{ACKNOWLEDGMENTS}

Thank you for the research grant from LPPM Universitas PGRI Semarang that was awarded our team.

\section{REFERENCES}

[1] Saputro, H. B., \& Soeharto. (2015). Pengembangan Media Komik Berbasis Pendidikan Karakter Pada Pembelajaran Tematik-Integratif, 3(3), 61-72.

[2] Bruun, F. (2013). Elementary Teachers 'Perspectives of Mathematics Problem Solving Strategies, 23(1), $45-59$.

[3] Sari, D. P. (2016). Penerapan Model Contextual Teaching Learning.

[4] Syahbana, A. (2012). Peningkatan Kemampuan Berpikir Kritis Matematis Siswa Smp Melalui Pendekatan Contextual Teaching and Learning, 02(April), 45-57.

[5] Zain, I. M. (2013). Instructional Media Integration Strategies for Basic Development of Human Capital: An approach to generate critical and 
creative minds in teaching and learning process, 2(2), 55-64.

[6] Romadiasri, Y., \& Maslikhah, S. (2016). Pengembangan Perangkat Pembelajaran melalui Digital BookBerbasis Scientifik Approach pada Mata Pelajaran Matematika Materi Limit Fungsi Pendahuluan Seiring dengan kemajuan zaman, dunia pendidikan diIndonesia terus, 4(1), 71-83.

[7] Nhiayi, K., \& Diego, S. (2012). Electronic Comic (EComic) Metadata Processing, 1(19).

[8] Laili, H. (2016). Pengaruh Model Pembelajaran Contextual Teaching and Learning (CTL) Dalam Meningkatkan Kemampuan Pemecahan Masalah Matematika Siswa MTs Nurul Hakim Kediri Ditinjau dari Segi Gender, 5, 34-52. https://doi.org/10.1021/jz5000879

[9] Oertle, S. K., \& Marie, K. (2010). The theory and application of contextualized teaching and learning in relation to programs of study and career pathways, (2).

[10] Rasiman, \& Pramasdyahsari, A. S. (2014). Development of Mathematics Learning Media EComic Based on Flip Book Maker to Increase the Critical Thinking Skill and Character of Junior High School Students. International Journal of Education and Research, 2(11), 535-544.

[11] Setiawati, R. (2010). Development Of Student Worksheet With E- Media, 89-95.

[12] Widayanti, C., Dwidayati, N., \& P.Hendikawati. (2014). Unnes Journal of Mathematics Education. Unnes Journal of Mathematics Education, 3(3). Retrieved from http://journal.unnes.ac.id/sju/index.php/ujme\%25

[13] Buchori, A., \& Setyawati, R. D. (2015). Development learning model of charactereducation through Digital Bookin elementary school. Inch Ternational Journal of Education and Resear, 3(9), 369-386. https://doi.org/92/1/116 [pii] \r10.1136/bjo.2007.126144 [doi]
[14] Astuti, E. P., Yuzianah, D., \& Purwoko, R. Y. (2018). Need Analysis Dalam Pengembangan Media Pengembangan Matematika E-Komik Untuk Siswa SMP. Jurnal Pendidikan Surya Edukasi (JPSE), 4(April), 10-18.

[15] Bahri, S., \& Nasution, A. S. (2019). Peningkatan Kemampuan Pemecahan Masalah Dan Kemandirian Belajar Siswa Melalui Pendekatan Contextual Teaching And Learning ( $\mathrm{Ctl}$ ), 474-483.

[16] Pribadi, \& Benny. (2010). Model Desain Sistem Pembelajaran. Jakarta: Dian Rakyat.

[17] Sugiyono. (2017). Metode penelitian Kuantitatif, Kualitatif, dan R\&D. Bandung: Alfabeta.

[18] Bamrara, A. (2018). Applying Addie Model To Evaluate Faculty Development Program, (1), 11-28.

[19] Prasetyowati, D. (n.d.). Pengembangan Perangkat Pembelajaran Matematika Berbasis Humanistik Dan Konstruktivisme Dengan Pendekatan Savi (Somatic Aaditory Visuel Intelleaual) Berbaitttuan Cd Interaktif Materi Segi Empat Kelas VII.

[20] Anggraeni, S. (2014). Pengembangan Perangkat Pembelajaran Dengan Pendekatan Contextual Teaching And Learning Berbantuan Modul Interaktif, 3(2252).

[21] Agustina, D. (2015). Pengembangan Modul Matematika Berbantu Cabri 3d Dengan Pendekatan PBL (Problem Based Learing) Pada Materi Persamaan Garis Lurus, 65-73.

[22] Buchori, A., Rasiman, Prasetyowati, D., \& Kartinah. (2015). Pengembangan Mobile Learning Pada Mata Kuliah Geometri Dengan Pendekatan Matematik Realistik Ditinjau Dari Kemampuan Berpikir Kritis Mahasiswa, 1(November), 113-121.

[23] Sari, N. T., \& Ikhsan, M. (2014). Implementasi Pendekatan Contextual Teaching and Learning (CTL) Bernuansa Pendidikan Karakter untuk Meningkatkan Kemampuan Pemecahan Masalah Matematis Siswa MTsN, 46-60. 